\title{
THIRTY-SECOND ANNUAL LIST OF PAPERS
}

\author{
READ BEFORE THE AMERICAN MATHEMATICAL SOCIETY AND \\ SUBSEQUENTLY PUBLISHED, INCLUDING REFERENCES \\ TO THE PLACES OF PUBLICATION
}

Alexander, J. W. A proof and extension of the Jordan-Brouwer separation theorem. Read April 29, 1916. Transactions of this Society, vol. 23, No. 4, pp. 333-349; June, 1922.

- Invariant points of a surface transformation of given class. Read Dec. 28, 1922. Transactions of this Society, vol. 25, No. 2, pp. 173184; April, 1923.

BARNETT, I. A. Differential equations with a continuous infinitude of variables. Read Dec. 28, 1918. American Journal of Mathematics, vol. 44, No. 3, pp. 172-190; July, 1922.

- Linear partial differential equations with a continuous infinitude of variables. Read Dec. 28, 1918, and April 24, 1920. American Journal of Mathematics, vol. 45, No. 1, pp. 42-53; Jan., 1923.

BeLL, E. T. On restricted systems of higher indeterminate equations. Read (San Francisco) June 18, 1920. Transactions of this Society, vol. 22, No. 4, pp. 483-488; Oct., 1921.

- Anharmonic polynomial generalizations of the numbers of Bernoulli and Euler. Read (San Francisco) April 9, 1921. Transactions of this Society, vol. 24, No. 2, pp. 89-112; Sept., 1922.

- Periodicities in the theory of partitions. Read (San Francisco) April 8, 1922. Annals of Mathematics, (2), vol. 24, No. 1, pp. 1-22; Sept., 1922.

- Relations between the numbers of Bernoulli, Euler, Genocchi, and Lucas. Read (San Francisco) April 8, 1922. Messenger of Mathematics, vol. 52, No. 4, pp. 56-64, and No. 5, pp. 65-68; Aug. and Sept., 1922.

- Euler algebra. Read (San Francisco) Oct. 22, 1921, and April 7, 1923. Transactions of this Society, vol. 25, No. 1, pp. 135-154; Jan., 1923.

- Singly infinite class number relations. Read (San Francisco) Oct. 23, 1920. Quarterly Journal of Mathematics, vol. 49, No. 4, pp. 322-337; March, 1923.

- Applications of analysis to the arithmetic of higher forms. Read (San Francisco) Oct. 21, 1922. Transactions of this Society, vol. 25, No. 2, pp. 185-189; April, 1923.

- Square-partition congruences. Read (San Francisco) April 7, 1923. This Bulletin, vol. 29, No. 8, pp. 349-355; Oct., 1923.

- Analogies between the $u_{n}, v_{n}$ of Lucas and elliptic functions. Read (San Francisco) Sept. 18, 1923. This Bulletin, vol. 29, No. 9, pp. 401-406; Nov., 1923.

BenNeTt, A. A. Normalized geometric systems. Read Oct. 30, 1920. Proceedings of the National Academy of Sciences, vol. 7, No. 3, pp. 84-89; March, 1921.

- Some algebraic analogies in matric theory. Read Feb. 28, 1920. Annals of Mathematics, (2), vol. 23, No. 1, pp. 91-96; Sept., 1921. Tables for interior ballistics. Read Feb. 26, 1921. Ordnance Department Document, No. 2039. Washington, Government Printing Office, 1923. $80 \mathrm{pp}$. 
Bernstein, B. A. On the complete independence of Hurwitz's postulates for abelian groups and fields. Read (San Francisco) Oct. 22, 1921, Annals of Mathematics, (2), vol. 23, No. 4, pp. 313-316; June, 1922.

BirkноғF, G. D. Circular plates of variable thickness. Read Sept. 8, 1921. Philosophical Magazine, ser. 6, vol. 43, No. 5, pp. 953-962; May, 1922.

Birkhoff, G. D., and Langer, R. E. The boundary problems and developments associated with a system of ordinary linear differential equations of the first order. Read Feb. 25, 1922. Proceedings of the American Academy of Arts and Sciences, vol. 58, No. 2, pp. 51-128; April, 1923.

BuIss, G. A. The reduction of singularities of plane curves by birational transformation. Read Dec. 28, 1922. This Bulletin, vol. 29, No. 4, pp. 161-183; April, 1923.

Blomberg, H. New properties of all real functions. Read March 29, 1919, and Dec. 30, 1920. Transactions of this Society, vol. 24, No. 2, pp. 113-128; Sept., 1922.

Bray, H. E. Proof of a formula for an area. Read Dec. 27, 1922. This Bulletin, vol. 29, No. 6, pp. 264-270; June, 1923.

BrinkmanN (H. W.). On Riemann spaces conformal to euclidean space. Read Dec. 27, 1922. Proceedings of the National Academy of Sciences, vol. 9, No. 1, pp. 1-3; Jan., 1923.

- On Riemann spaces conformal to Einstein spaces. Read April 28, 1923. Proceedings of the National Academy of Sciences, vol. 9, No. 5, pp. 172-174; May, 1923.

Buchanan, D. Asymptotic planetoids. Read Dec. 31, 1919. Transactions of this Sociely, vol. 23, No. 4, pp. 409-431; June, 1922.

Bussex, W. H. A note on the problem of eight queens. Read March 28, 1919. American Mathematical Monthly, vol. 29, No. 7, pp. 252-253; Aug., 1922.

Cajorr, F. Origin of the names arithmetical and geometrical progression and proportion. Read (San Francisco) Oct. 21, 1922. School Science and Mathematics, vol. 22, No. 8, pp. 734-737; Nov., 1922.

- Mathematical signs of equality. Read Dec. 27, 1922. Isis, vol. 5, No. 1 , pp. 116-125; 1923.

- The origin of the symbols for "degrees, minutes, and seconds." Read (San Francisco) Oct. 21, 1922. American Mathematical Monthly, vol. 30, No. 2, pp. 65-66; Feb., 1923.

- Recent symbolisms for decimal fractions. Read (San Francisco) April 8, 1922. Mathematics Teacher, vol. 16, No. 3, pp. 183-187; March, 1923.

- Varieties of minus signs. Read (San Francisco) April 7, 1923. Mathematics Teacher, vol. 16, No. 5, pp. 295-301; May, 1923.

- The evolution of our exponential notation. Read (San Francisco) April 7, 1923. School Science and Mathematics, vol. 23, No. 6, pp. 573-581; June, 1923.

- Grafting of the theory of limits on the calculus of Leibniz. Read Dec. 28, 1922. American Mathematical Monthly, vol. 30, No. 5, pp. 223-234; July-Aug., 1923.

CAMp, C. C. Expansions in terms of solutions of partial differential equations. First paper: Multiple Fourier series expansions. Read Sept. 7, 1922. Transactions of this Society, vol. 25, No. 1, pp. 123-134; Jan., 1923. 
CANDY, A. L. Cyclic operations on determinants. Read (Southwestern Section) Dec. 2, 1922. American Mathematical Monthly, vol. 30, No. 3, pp. 113-120; March-April, 1923.

Carmichater, R. D. Boundary value and expansion problems: oscillation, comparison, and expansion theorems. Read April 10, 1920. American Journal of Mathematics, vol. 44, No. 2, pp. 129-152; April, 1922.

Carver, W. B. Systems of linear inequalities. Read Dec. 29, 1920. Annals of Mathematics, (2), vol. 23, No. 3, pp. 212-220; March, 1922.

Chittenden, E. W. On a theorem in general analysis and the interrelations of eight fundamental properties of classes of functions. Read April 21, 1916. American Journal of Mathematics, vol. 44, No. 2, pp. 153-162; April, 1922.

CoвLe, A. B. Associated sets of points. Read Dec. 29, 1922. Transactions of this Society, vol. 24, No. 1, pp. 1-20; July, 1922.

- Geometric aspects of the abelian modular functions of genus four (III). Read Dec. 31, 1919. Proceedings of the National Academy of Sciences, vol. 9, No. 6, pp. 183-187; June, 1923.

Coolidge, J. L. The Gaussian law of error for any number of variables. Read Dec. 27, 1922. Transactions of this Society, vol. 24, No. 2, pp. 135-143; Sept., 1922.

Craig, C. F. On the Riemann zeta function. Read Dec. 27, 1922. This Bulletin, vol. 29, No. 8, pp. 337-340; Oct., 1923.

Crom, W. L. The use of the median in determining seasonal variation. Read Oct. 28, 1922. Journal of the American Statistical Association, vol. 18, No. 141, pp. 607-614; March, 1923.

The resemblance between the ordinate of the periodogram and the correlation coefficient. Read April 28, 1923. Journal of the American Statistical Association, vol. 18, No. 143, pp. 889-899; Sept., 1923.

- Note on the reliability of a test, with special reference to the examinations set by the College Entrance Board. Read Oct. 28, 1922. American Mathematical Monthly, vol. 30, No. 6, pp. 296-301; Sept.Oct., 1923.

Curtiss, D. R. A note on the preceding paper (by J. L. Walsh). Read April 14, 1922. Transactions of this Society, vol. 24, No. 3, pp. 181184; Oct., 1922.

- On Kellogg's diophantine problem. Read Dec. 28, 1921. American Mathematical Monthly, vol. 29, No. 10, pp. 380-387; Nov.-Dec., 1922.

Relations between kindred Riemannian $P$ and $Q$ functions. Read April 14, 1922. This Bulletin, vol. 29, No. 4, pp. 154-160; April, 1923.

DaUs, P. H. Normal ternary continued fraction expansions for the cube roots of integers. Read (San Francisco) April 9, 1921. American Journal of Mathematics, vol. 44, No. 4, pp. 279-296; Oct., 1922.

Dickson, L. E. Algebras and their arithmetics. Read April 17, 1923. Chicago, University of Chicago Press, 1923.

- Integral solutions of $x^{2}-m y^{2}=z w$. Read (Southwestern Section) Dec. 1, 1923. This Bulletin, vol. 29, No. 10, pp. 464-467; Dec., 1923.

Dines, L. L. A primary classification of projective transformations in function space. Read Sept. 3, 1919. American Journal of Mathematics, vol. 44, No. 2, pp. 87-101; April, 1922.

Douglas, J. On certain two-point properties of general families of curves. Read April 28, 1917. Transactions of this Society, vol. 22, No. 3, pp. 289-310; July, 1921.

- Determination of all systems of $\infty^{4}$ curves in space in which the sum of the angles of every triangle is two right angles. Read April 28, 1923. This Bulletin, vol. 29, No. 8, pp. 356-366; Oct., 1923. 
Dresden, A. On the second derivatives of an extremal-integral with an application to a problem with variable end points. (Supplementary paper.) Read Dec. 28, 1914. Transactions of this Society, vol. 25, No. 2, pp. 190-192; April, 1923.

Dushman, S. Some recent applications of the quantum theory to spectral series. Read Dec. 29, 1921. Journal of the Optical Society of America, vol. 6 , No. 3, pp. 235-250; May, 1922.

Edington, W. E. Abstract group definitions and applications. Read Dec. 29, 1922. Transactions of this Society, vol. 25, No. 2, pp. 193-210; April, 1923.

EisenharT, L. P. Orthogonal systems of hypersurfaces in a general Riemann space. Read April 28, 1923. Transactions of this Society, vol. 25, No. 2, pp. 259-280; April, 1923.

- Symmetric tensors of the second order whose first covariant derivatives are zero. Read April 28, 1923. Transactions of this Society, vol. 25, No. 2, pp. 297-306; April, 1923.

Емсн, A. On plane algebraic curves which are invariant under a quadratic transformation. Read Dec. 28, 1921. Tóhoku Mathematical Journal, vol. 21, Nos. 3-4, pp. 310-326; Oct., 1922.

EtTlinger, H. J. Cauchy's paper of 1814 on definite integrals. Read Sept. 2, 1919. Annals of Mathematics, (2), vol. 23, No. 3, pp. 255-270; March, 1922.

- An elementary proof of a fundamental lemma concerning the limit of a sum. Read Sept. 7, 1922. This Bulletin, vol. 29, No. 5, pp. 219-223; May, 1923.

Evans, G. C. Fundamental points of potential theory. Read Sept. 4, 1919, and Dec. 30, 1920. The Rice Institute Pamphlet, vol. 7, No. 4, pp. 252-329; Oct., 1920.

- A simple theory of competition. Read Sept. 7, 1922. American Mathematical Monthly, vol. 29, No. 10, pp. 371-380; Nov.-Dec., 1922.

- A Bohr-Langmuir transformation. Read Sept. 7, 1922. Proceedings of the National Academy of Sciences, vol. 9, No. 7, pp. 230-236; July, 1923.

Everetr, H. S. Determination of all general homogeneous polynomials expressible as determinants whose elements are homogeneous polynomials. Read Dec. 28, 1921. Transactions of this Society, vol. 24, No. 3, pp. 185-194; Oct., 1922.

Feldstein, M. M. Invariants of the linear group modulo $p^{k}$. Read April 13, 1923. Transactions of this Society, vol. 25, No. 2, pp. 223238; April, 1923.

Fischer, C. A. The kernel of the Stieltjes integral corresponding to a completely continuous transformation. Read April 23, 1921. American Journal of Mathematics, vol. 44, No. 4, pp. 237-246; Oct., 1922.

Fite, W. B. Properties of the solutions of certain functional differential equations. Read April 26,1919, and Dec. 31, 1919. Transactions of this Society, vol. 22, No. 3, pp. 311-319; July, 1921.

FrankLin, P. A qualitative definition of the trigonometric and hyperbolic functions. Read Dec. 27, 1922. This Bulletin, vol. 29, No. 2, pp. 56-64; Feb., 1923.

- Tensors of given type in Riemann space. Read Dec. 27, 1922. Philosophical Magazine, ser. 6, vol. 45, No. 5, pp. 998-1009; May, 1923.

GABA, M. G. A set of axioms for line geometry. Read (Southwestern Section) Nov. 27, 1920. This Bulletin, vol. 29, No. 3, pp. 128-138; March, 1923. 
Goкнale, V. D. Concerning compact Kürschák fields. Read April 15, 1922. American Journal of Mathematics, vol. 44, No. 4, pp. 297-316; Oct., 1922.

Graustein, W. C. Parallel maps of surfaces. Read Dec. 31, 1919, and Dec. 28,1920 . Transactions of this Society, vol. 23 , No. 3, pp. 298332; April, 1922.

Note on a certain type of ruled surface. Read April 28, 1923. This Bulletin, vol. 29, No. 8, pp. 341-344; Oct., 1923.

Gronwall, T. H. Differential variations in ballistics, with applications to the qualitative properties of the trajectory. Read Oct. 25, 1919. Transactions of this Society, vol. 22, No. 4, pp. 505-525; Oct., 1921.

- Summation of a double series. Read Feb. 26, 1921. Annals of Mathematics, (2), vol. 23, No. 3, pp. 282-285; June, 1922.

- On power series with positive real part in the unit circle. Read Sept. 8, 1921. Annals of Mathematics, (2), vol. 23, No. 4, pp. 317-332; June, 1922.

Gummer, C. F. The relative distribution of the real roots of a system of polynomials. Read Sept. 7, 1920. Transactions of this Society, vol. 23, No. 3, pp. 265-282; April, 1922.

HART, W. L. Functionals of summable functions. Read Dec. 30, 1920. Annals of Mathematics, (2), vol. 24, No. 1, pp. 23-38; Sept., 1922.

HAZLETT, O. C. Annihilators of modular invariants and covariants. Read Sept. 7, 1920. Annals of Mathematics, (2), vol. 23, No. 3, pp. 198-211; March, 1922.

HILDEBRANDT, T. H. On uniform limitedness of sets of functional operations. Read March 26, 1921. This Bulletin, vol. 29, No. 7, pp. 309315; July, 1923.

HiLle, E. Zeros of Legendre functions. Read Dec. 29, 1920. Arkiv för Matematik, Astronomi och Fysik, vol. 17, No. 22, pp. 1-16; 1922.

- Oscillation theorems in the complex domain. Read Oct. 28, 1922. Transactions of this Society, vol. 23, No. 4, pp. 350-385; June, 1922.

HIтснсоск, F. L. A method for the numerical solution of integral equations. Read Dec. 28, 1922. Journal of Mathematics and Physics of the Massachuselts Institute of Technology, vol. 2, No. 2, pp. 88-104; March, 1923.

HollCROFT, T. R. Plane involutions of order four. Read April 24, 1920. American Journal of Mathematics, vol. 44, No. 3, pp. 163-171; July, 1922.

- Singularities of curves of given order. Read April 28, 1923. This Bulletin, vol. 29, No. 9, pp. 407-414; Nov., 1923 .

HuRwitz, W. A. An expansion theorem for a system of linear differential equations of the first order. Read Sept. 5, 1917. Transactions of this Society, vol. 22, No. 4, pp. 526-543; Oct., 1921.

$\mathrm{J}_{\text {ACKSON, }} \mathrm{D}$. Note on a class of polynomials of approximation. Read Sept. 8, 1920. Transactions of this Society, vol. 22, No. 3, pp. 320326; July, 1921.

- Note on quartiles and allied measures. Read Oct. 28, 1922. This Bulletin, vol. 29, No. 1, pp. 17-20; Jan., 1923.

- Note on the convergence of weighted trigonometric series. Read Dec. 30, 1920. This Bulletin, vol. 29, No. 6, pp. 259-263; June, 1923.

Karpinski, L. C. Two twelfth century algorisms. Read Sept. 9, 1914. Isis, vol. 3, No. 3, pp. 396-413; 1921.

KAKEYA, S. Maximum modulus of some expressions of limited analytic functions. Read Feb. 24, 1923. Transactions of this Society, vol. 22, No. 4, pp. 489-504; Oct., 1921. 
Kelloga, O. D. An example in potential theory. Read Sept. 8, 1922. Proceedings of the American Academy of Arts and Sciences, vol. 58, No. 14, pp. 527-533; June, 1923.

KEMPNer, A. J. Polynomials and their residue systems (continued). Read Dec. 30, 1920. Transactions of this Society, vol. 22, No. 3, pp. 267-288; July, 1921.

Kendall, C. Congruences determined by a given surface. Read (Southwestern Section) Nov. 26, 1921. American Journal of Mathematics, vol. 45 , No. 1, pp. 25-41; Jan., 1923.

KuINE, J. R. Closed connected point sets which are disconnected by the removal of a finite number of points. Read April 23, 1921. Proceedings of the National Academy of Sciences, vol. 9, No. 1, pp. 7-12; Jan., 1923.

LANE, E. P. A general theory of conjugate nets. Read March 26, 1921. Transactions of this Society, vol. 23, No. 3, pp. 283-297; April, 1922.

- Ruled surfaces with generators in one-to-one correspondence. Read April 15, 1922, and Dec. 29, 1922. Transactions of this Society, vol. 25, No. 2, pp. 281-296; April, 1923.

LANGER, R. E. Developments associated with a boundary problem not linear in the parameter. Read Feb. 25, 1922. Transactions of this Society, vol. 25, No. 2, pp. 155-172; April, 1923. See Birkhoff, G. D.

LEFscheTz, S. On certain numerical invariants of algebraic varieties with application to abelian varieties. Read (Southwestern Section) Nov. 27, 1920. Transactions of this Society, vol. 22, No. 3, pp. 327406, and No. 4, pp. 407-482; July and Oct., 1921.

- Continuous transformations of manifolds. Read April 13, 1923. Proceedings of the National Academy of Sciences, vol. 9, No. 3, pp. 90-93; March, 1923.

- Report on curves traced on algebraic surfaces. Read April 13, 1923. This Bulletin, vol. 29, No. 6, pp. 242-258; June, 1923.

LINFIELD, B. Z. On certain polar curves with their application to the location of the roots of the derivatives of a rational function. Read Oct. 28, 1922. Transactions of this Society, vol. 25, No. 2, pp. 239-258; April, 1923.

LIPKA, J. On Hamilton's canonical equations and infinitesimal contact transformations. Read Dec. 28, 1921. Journal of Mathematics and Physics of the Massachusetts Institute of Technology, vol. 2, No. 1, pp. 31-46; Dec., 1922.

- On irreversible dynamical systems. Read Dec. 27, 1922. Journal of Mathematics and Physics of the Massachusetts Institute of Technology, vol. 2, No. 2, pp. 73-87; March, 1923.

- On conformal parallelism. Read Dec. 27, 1922. Journal of Mathematics and Physics of the Massachusetts Institute of Technology, vol. 2, No. 3, pp. 175-194; May, 1923.

- Trajectory surfaces and a generalization of the principal directions in any space. Read Ap;il 28, 1923. Proceedings of the American Academy of Arts and Scienres, vol. 59, No. 3, pp. 51-77; Sept., 1923.

- On the relative curvature of two curves in $V_{n}$. Read Feb. 24, 1923. This Bulletin, vol. 29, No. 8, pp. 345-348; Oct., 1923.

LOGSDON, M. I. Equivalunce and reduction of pairs of hermitian forms. Read March 25, 1921. American Journal of Mathematics, vol. 44, No. 4, pp. 247-260; Oct., 1922.

MACDUFHEE, C. C. On transformable systems and covariants of algebraic forms. Read Dec. 28, 1922. This Bulletin, vol. 29, No. 1, pp. 2633; Jan., 1923. 
MacNeish, H. F. Euler squares. Read Dec. 28, 1921. Annals of Mathematics, (2), vol. 23, No. 3, pp. 221-227; March, 1922.

MANNEBACK, C. An integral equation for skin effect in parallel conductors. Read Feb. 25, 1922. Journal of Mathematics and Physics of the Massachusetts Institute of Technology, vol. 1, No. 3, pp. 123-146; April, 1922.

MILLER, G. A. Substitution groups whose cycles of the same order contain a given number of letters. Read April 14, 1922 . American Journal of Mathematics, vol. 44, No. 2, pp. 122-128; April, 1922.

- I-conjugate operators of an abelian group. Read Dec. 30, 1920. Transactions of this Society, vol. 24, No. 1, pp. 70-78; July, 1922.

- Contradictions in the literature of group theory. Read Dec. 28, 1921. American Mathematical Monthly, vol. 29, No. 9, pp. 319-328; Oct., 1922.

- Groups in which the number of operators in a set of conjugates is equal to the order of the commutator subgroup. Read Sept. 7, 1922. This Bulletin, vol. 29, No. 2, pp. 64-70; Feb., 1923.

- Same left co-set and right co-set multipliers for any finite group. Read April 13, 1923. This Bulletin, vol. 29, No. 9, pp. 394-398; Nov., 1923.

Moore, C. L. E. Note on the vanishing of the determinant of the second fundamental form of a hypersurface. Read Dec. 27, 1922. Journal of Mathematics and Physics of the Massachusetts Institute of Technology, vol. 2, No. 2, pp. 125-130; March, 1923.

MOORE, C. N. Generalized limits in general analysis, first paper. Read Dec. 28, 1918. Transactions of this Society, vol. 24, No. 2, pp. 7988; Sept., 1922.

- Sur les séries de Fourier généralisées des fonctions non intégrables. Read Sept. 9, 1921. Comptes Rendus de l'Académie des Sciences, vol. 176, No. 22, pp. 1536-1537; May 28, 1923.

- Sur la sommabilité de Cesàro pour la série double de Fourier. Read Dec. 28, 1922. Comptes Rendus de l'Académie des Sciences, vol. 176, No. 24, pp. 1691-1693; June 11, 1923.

Moore, R. L. Concerning continuous curves in the plane. Read Oct. 29, 1921. Mathematische Zeitschrift, vol. 15, Nos. 3-4, pp. 254-260; Dec., 1922.

- On the generation of a simple surface by means of a set of equicontinuous curves. Read Feb. 23, 1918. Fundamenta Mathematica, vol. 4, pp. 106-117; 1923.

- An uncountable, closed and non-dense point set each of whose complementary intervals abuts on another one at each of its ends. Read Dec. 29, 1922. This Bulletin, vol. 29, No. 2, pp. 49-50; Feb., 1923.

- Concerning the cut-points of continuous curves and of other closed and connected point sets. Read April 14, 1922. Proceedings of the National Academy of Sciences, vol. 9, No. 4, pp. 101-106; April, 1923.

- Report on continuous curves from the viewpoint of analysis situs. Read (Southwestern Section) Dec. 2, 1922. This Bulletin, vol. 29, No. 7, pp. 289-302; July, 1923.

MORDELL, L. J. An introductory account of the arithmetical theory of algebraic numbers and its recent development. Read Sept. 6, 1923. This Bulletin, vol. 29, No. 10, pp. 445-463; Dec., 1923.

MorITz, R. E. Ueber gewisse Infinitesimaloperationen der höheren Operationsstufen. Teil III. Read (San Francisco) Oct. 22, 1921. Tóholu Mathematical Journal, vol. 22, Nos. 3-4, pp. 223-240; May, 1923. 
MULlikin, A. M. Certain theorems relating to plane connected point sets. Read Oct. 25, 1919, Dec. 28, 1920, and Feb. 26, 1921. Transactions of this Society, vol. 24, No. 2, pp. 144-162; Sept., 1922.

Murray, F. H. On certain linear differential equations of the second order. Read Dec. 28, 1922. Annals of Mathematics, (2), vol. 24, No. 1, pp. 69-88; Sept., 1922.

- Periodic solutions in the problem of three bodies. Read Sept. 8, 1922. This Bulletin, vol. 29, No. 1, pp. 15-16; Jan., 1923.

Musselman, J. R. Spurious correlation applied to urn schemata. Read Sept. 9, 1921. Journal of the American Statistical Association, vol. 18, No. 143, pp. 908-911; Sept., 1923.

NöRLond, N. E. Sur certaines équations aux différences finies. Read April 28, 1923. Transactions of this Society, vol. 25, No. 1, pp. 13-98; Jan., 1923.

Osqood, W. F. On the gyroscope. Read April 23, 1921. Transactions of this Society, vol. 23, No. 3, pp. 240-264; April, 1922.

PhILlips, H. B. Mathematical aspects of quantum theory. Read Dec. 29, 1921. Journal of the Optical Society of America, vol. 6, No. 3, pp. 229-234; May, 1922.

Phillips, H. B., and Wiener, N. Nets and the Dirichlet problem. Read Dec. 28, 1922. Journal of Mathematics and Physics of the Massachusetts Institute of Technology, vol. 2, No. 2, pp. 105-124; March, 1923.

Pinrpont, J. Geometric aspects of Einstein's theory. Read Sept. 7, 1921. Annals of Mathematics, (2), vol. 23, No. 3, pp. 228-254; March, 1922.

PorITsky, H. On curves kinematically related to a given curve. Read Dec. 28, 1922. This Bulletin, vol. 29, No. 2, pp. 71-78; Feb., 1923.

Porter, M. B. The second mean value theorem for summable functions. Read (San Francisco) Sept. 18, 1923. This Bulletin, vol. 29, No. 9, pp. 399-400; Nov., 1923.

RAINICH, G. Y. Tensor analysis without coordinates. Read April 28, 1923. Proceedings of the National Academy of Sciences, vol. 9, No. 6, pp. 179-183; June, 1923.

RaYnor, G. E. Dirichlet's problem. Read Dec. 28, 1922. Annals of Mathematics, (2), vol. 23, No. 3, pp. 183-197; March, 1922.

Richardson, R. G. D. On the reality of the zeros of a lambda determinant. Read Oct. 27, 1923 . This Bulletin, vol. 29, No. 10, pp. 467469; Dec. 1923.

RiwTz, H. L. Frequency distributions obtained by certain transformations of normally distributed variates. Read (Southwestern Section) Nov. 27, 1920. Annals of Mathematics, (2), vol. 23, No. 4, pp. 292-300; June, 1922.

RITT, J. F. On algebraic functions which can be expressed in terms of radicals. Read Oct. 30, 1920, and Oct. 29, 1921. Transactions of this Society, vol. 24, No. 1 pp 21-30; July, 1922.

- Sur les fonctions rationnelles permutables. Read Feb. 24, 1923. Comptes Rendus de l'Académie des Sciences, vol. 176, No. 2, pp. 60-61; Jan. 8, 1923.

- On the integrals of elementary functions. Read Feb. 25, 1922. Transactions of this Society, vol. 25, No. 2, pp. 211-222; April, 1923.

RUTledae, G. The polynomial determined by $2 n+1$ points. Read Dec. 28, 1922. Journal of Mathematics and Physics of the Massachusetts Institute of Technology, vol. 2, No. 1, pp. 47-62; Dec., 1922. 
Sharpe, F. R., and Snyder, V. The $(2,1)$ correspondence associated with the cubic space involution of order two. Read Sept. 7, 1922. Transactions of this Society, vol. 25, No. 1, pp. 1-12; Jan., 1923.

SHAw, J. B. General vector calculus. Read Nov. 27, 1909, Dec. 31, 1909, Jan. 2, 1913, Dec. 26, 1913, Dec. 31, 1915, and March 26, 1921. Transactions of this Society, vol. 24, No. 3, pp 195-244; Oct., 1922.

SNyder, V. See Sharpe, F. R.

TAYLOR, J. S. A four-space representation of complex plane analytics. Read Dec. 27, 1922. Journal of Mathematics and Physics of the Massachusetts Institute of Technology, vol. 2, No. 1, pp. 1-30; Dec., 1922.

Tolman, R. C. Review of the present status of the two forms of quantum theory. Read Dec. 29, 1921. Journal of the Optical Society of America, vol. 6, No. 3, pp. 211-228; May, 1922.

TURner, J. S. A fundamental system of invariants of a modular group of transformations. Read April 15, 1922. Transactions of this Society, vol. 24, No. 2, pp. 129-134; Sept., 1922.

Veblen, O. Projective and affine geometry of paths. Read Oct. 28, 1922. Proceedings of the National Academy of Sciences, vol. 8, No. 12, pp. 347-350; Dec., 1922.

- Geometry and physics. Read Dec. 28, 1922. Science, newser., vol. 57, No. 1466, pp. 129-139; Feb. 2, 1923.

WAHLIN, G. E. The factorization of the rational primes in a cubic domain. Read Dec. 22, 1916. American Journal of Mathematics, vol. 44, No. 3, pp. 191-203; July, 1922.

WALSH, J. L. A theorem on loci connected with cross-ratios. Read Oct. 29, 1921. Rendiconti del Circolo Matematico di Palmero, vol. 46, Nos. 2-3, pp. 236-248; May-Dec., 1922.

- On the location of the roots of the jacobian of two binary forms, and of the derivative of a rational function. Read Sept. 9, 1921. Transactions of this Society, vol. 24, No. 1, pp. 31-69; July, 1922.

- On the location of the roots of certain types of polynomials. Read Dec. 29, 1920, and April 23, 1921. Transactions of this Society, vol. 24, No. 3, pp. 163-180; Oct., 1922.

- A closed set of normal orthogonal functions. Read Feb. 25, 1922. American Journal of Mathematics, vol. 45, No. 1, pp. 5-24; Jan., 1923.

- A property of Haar's system of orthogonal functions. Read Feb. 24, 1923. Mathematische Annalen, vol. 90, Nos. 1-2, pp. 38-45; Sept., 1923.

Wraver, J. H. A generalization of the strophoid. Read Sept. 7, 1920. American Mathematical Monthly, vol. 29, No. 5, pp. 204-207; May, 1922.

WeISNer, L. Groups whose maximal cyclic subgroups are independent. Read Dec. 28, 1922. Author's dissertation. New York, 1923. $17 \mathrm{pp}$.

WhiтE, H. S. The associated point of seven points in space. Read April 23,1921 . Annals of Mathematics, (2), vol. 23, No. 4, pp. 301-306; June, 1922.

WhitTEMoRe, J. K. Ruled surfaces with director planes. Read April 23, 1921. This Bulletin, vol. 29, No. 1, pp. 21-25; Jan., 1923.

- Total geodesic curvature and geodesic torsion. . Read Oct. 29, 1921. This Bulletin, vol. 29, No. 2, pp. 51-54; Feb., 1923.

Wiener, N. Differential-space. Read Dec. 27, 1922. Journal of Mathematics and Physics of the Massachuselts Institute of Technology, vol. 2, No. 3, pp. 131-174; May, 1923.

- See Phillips, H. B. 
WrLczynski, E. J. Some generalizations of geodesics. Read March 25, 1921. Transactions of this Society, vol. 23, No. 3, pp. 223-239; April, 1922.

WILDER, C. E. Differential geometry of an $m$-dimensional manifold in a euclidean space of $n$ dimensions. Read Dec. 28, 1921. Transactions of this Society, vol. 25, No. 1, pp. 99-122; Jan., 1923.

Williams, K. P. The Laplace-Poisson mixed equation. Read April 15, 1922. American Journal of Mathematics, vol. 44, No. 3, pp. 217-224; July, 1922.

Wood, F. E. On certain relations between the projective theory of surfaces and the projective theory of congruences. Read March 26, 1921. Transactions of this Society, vol. 23, No. 4, pp. 386-408; June, 1922.

- A graphical treatment of mixtures. Read April 13, 1923. American Mathematical Monthly, vol. 30, No. 5, pp. 243-249; July-Aug., 1923.

ZELDIN, S. D. On the structure of finite continuous groups with a single exceptional infinitesimal transformation. Read Dec. 31, 1919. American Journal of Mathematics, vol. 44, No. 3, pp. 204-216; July, 1922.

- Conformal transformations of linear homogeneous difference equations and their invariants. Read April 14, 1922. Journal of Mathematics and Physics of the Massachusetts Institute of Technology, vol. 2, No. 1, pp. 63-72; Dec., 1922. 